This is an accepted manuscript of an article published by Taylor \& Francis Group in International Journal of Remote Sensing on April 24, 2016. Subject to 12 months' embargo period, embargo end date: April 24, 2017.

The version of record, Young Min Noh, Sung-Kyun Shin, Kwonho Lee, Detlef Müller \& Kwanchul Kim (2016) "Utilization of the depolarization ratio derived by AERONET Sun/sky radiometer data for type confirmation of a mixed aerosol plume over East Asia", International Journal of Remote Sensing, 37(10): 2008-2025, is available on line at DOI: 10.1080/01431161.2016.1176274 

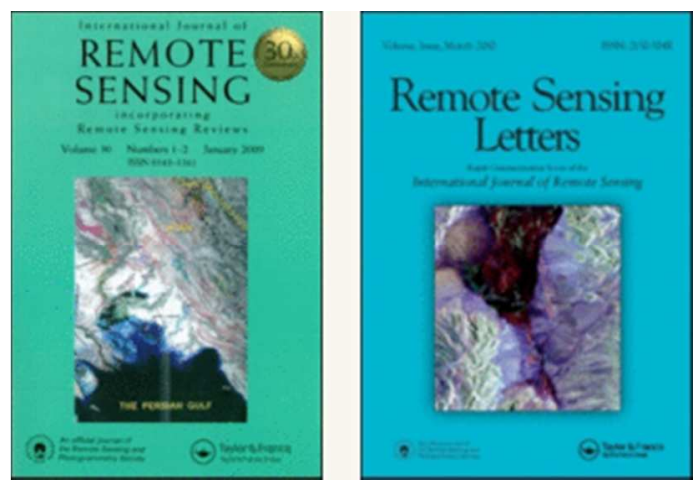

\section{Utilization of Depolarization Ratio derived by AERONET Sun/Sky Radiometer Data for Type Confirmation of a Mixed Aerosol Plume over East Asia}

\begin{tabular}{|c|c|}
\hline Journal: & International Journal of Remote Sensing \\
\hline Manuscript ID & TRES-PAP-2015-0873.R2 \\
\hline Manuscript Type: & IJRS Research Paper \\
\hline Date Submitted by the Author: & $\mathrm{n} / \mathrm{a}$ \\
\hline Complete List of Authors: & $\begin{array}{l}\text { Noh, Youngmin; Gwangju Institute of Science \& Technology (GIST), } \\
\text { International Environmental Research Center } \\
\text { Shin, Sung-Kyun; Gangneung-Wonju National University, Department of } \\
\text { Atmospheric and Environmental Sciences } \\
\text { Lee, Kwonho ; Gangneung-Wonju National University, Department of } \\
\text { Atmospheric and Environmental Sciences } \\
\text { Mueller, Detlef; University of Hertfordshire, School of Physics, Astronomy } \\
\text { and Mathematics } \\
\text { Kim, Kwanchul; Gwangju Institute of Science \& Technology (GIST), School } \\
\text { of Environmental Science and Engineering }\end{array}$ \\
\hline Keywords: & aerosols, lidar \\
\hline Keywords (user defined): & depolarization ratio, sun/sky radiometer, size distribution \\
\hline
\end{tabular}

\section{SCHOLARONE ${ }^{\text {m }}$}

Manuscripts 


\section{Radiometer Data for Type Confirmation of a Mixed Aerosol Plume over}

\section{East Asia}

4

5 Young Min Noh ${ }^{1}$, Sung-Kyun Shin $^{2}$, Kwonho Lee ${ }^{3}$, Detlef Müller ${ }^{4}$, and Kwanchul Kim ${ }^{2 *}$

6

$7 \quad{ }^{1}$ International Environmental Research Center, Gwangju Institute of Science \& Technology

$9 \quad{ }^{2}$ School of Environmental Science and Engineering, Gwangju Institute of Science \&

$21{ }^{*}$ Corresponding Author

22 Kwanchul Kim

23 Tel.: +82-62-715-2830

24 Fax: +82-62-715-3404

25 Email: fehouse@gmail.com 
ABSTRACT

This paper confirms utilization of depolarization ratio derived by Ground-based Aerosol

Robotics Network (AERONET) sun/sky radiometer data obtained during a high-PM $\mathrm{P}_{10}$ episode at Gwangju, Korea $\left(35.10^{\circ} \mathrm{N}, 126.53^{\circ} \mathrm{E}\right)$ in April 2009 , in order to determine the nature and source of the atmospheric aerosol associated with this event. Integrated monitoring using satellite and depolarization lidar data, together with model analysis, was also completed for the period of the high- $\mathrm{PM}_{10}$ event. The sun/sky radiometer-derived particle depolarization ratio values are similar to the lidar-derived values, and these values highlight the effect of dust particles on aerosol observation. High particle depolarization ratios $(12.5-14.2 \%)$ were shown when the aerosol plume transported from the west between April 5 and 7. In contrast, lower particle depolarization ratios (5.8 - $9.8 \%)$ were detected when the aerosol plume was transported from north in other observation days. Different optical properties are also shown according to variation of depolarization ratio. High values in the real part of the refractive index $(1.47-1.49$ at $440 \mathrm{~nm})$, lower values in the imaginary part of the refractive index $(0.007-0.009$ at $440 \mathrm{~nm})$, and a high proportion of coarser

41 particles were observed during high depolarization ratio period. In contrast, the atmospheric 42 aerosol transported from the north showed characteristics more commonly associated with smoke, with lower values in the real part of the refractive index $(1.41-1.48$ at $440 \mathrm{~nm})$, higher values in the imaginary part of the refractive index $(0.008-0.011)$, and a high proportion of fine particles. This indicates that the sun/sky radiometer-derived depolarization ratio is a useful parameter when estimating the effect of dust particles during high- $\mathrm{PM}_{10}$ 47 events.

Key words: aerosols, lidar, depolarization ratio, sun/sky radiometer, size distribution 
51 East Asia is one of the main global sources of atmospheric aerosol. This aerosol consists 52 of anthropogenic aerosols originating from urban/industrial areas and natural aerosol such as 53 dust from desert regions of central Asia, as well as smoke from forest fires in Siberia and 54 agricultural burning (Murayama et al., 2004; Lee et al., 2005; Noh et al., 2011). Such aerosols 55 have been studied previously within the context of their radiative effects and uncertain 56 influences on climate forcing (Stocker et al., 2013). The importance of these aerosols to 57 climate change is expected to increase in the future (Takemura et al., 2005). There are main 58 types of atmospheric aerosols: (i) urban-industrial aerosol derived from fossil fuel 59 combustion in populated industrial regions; (ii) biomass burning aerosol produced by forest 60 and grassland fires; (iii) desert dust blown into the atmosphere by wind; and (iv) aerosol of 61 marine origin (Dubovik et al., 2002). The significant differences in the optical properties of 62 these main general aerosol types have been extensively studied (Dubovik et al., 2002; Eck et 63 al., 2005; Russel et al., 2010; Utry et al., 2014). Eck et al. (2010) and Giles et al. (2012) have 64 been studied about the mixture of dust and pollution particles mainly forcing on the variation 65 of single-scattering albedo. However, there has been little analysis of mixed aerosol types, 66 especially in Asian dust mixed cases in East Asia. Dust particles show definitely different 67 optical properties with other aerosols (Dubovik et al., 2002; Russel et al., 2010; Hess et al., $68 \quad 1998)$.

South Korea is located in the downwind area from China in East Asia and is therefore an 70 important region for observations of atmospheric aerosols; e.g., dust, smoke, and 71 anthropogenic aerosols transported by westerly winds (Noh et al., 2008, 2009, 2011). 72 Moreover, the different types of atmospheric aerosol generated in the individual source 73 regions usually flow into Korea simultaneously (Noh et al., 2014). Thus, the observation of 
74 atmospheric aerosols in Korea requires further investigation, as the inflow of aerosol from 75 multiple sources makes the determination and identification of aerosol properties a 76 challenging task. To date, a large number of surface sampling measurements have been 77 conducted to investigate atmospheric aerosol properties in Korea (Kim et al., 2008; Lasserre et al., 2008; Moon et al., 2008; Sahu et al., 2009; Jung et al., 2011). These surface sampling measurements, although frequently providing excellent data regarding aerosol mass concentrations and their chemical/physical properties, have been limited to ground concentrations, and it remains difficult to generate real-time data from such measurements.

In contrast, ground-based remote sensing of aerosol using wide angular and spectral measurements of solar and sky radiation are well-suited for detailed, reliable, and continuous monitoring of aerosol optical properties (Dubovik et al., 2002). Although ground-based aerosol remote sensing is widely used to monitor main aerosol, easy and specific method is not applied to quantitative analysis of mixed aerosol plumes until now.

The main purpose of this study is verifying the usefulness of the depolarization ratio derived by Ground-based Aerosol Robotics Network (AERONET) sun/sky radiometer data for the type classification of mixed aerosols. The data by satellite and depolarization lidar system is investigated to understand the transportation and distribution of atmospheric aerosols. The Hybrid Single Particle Lagrangian Integrated Trajectories (HYSPLIT) model and reanalysis data from the Monitoring Atmospheric Composition and Climate (MACC) model were also used to supplement the classification and identification of the origin of atmospheric aerosols. The remainder of this paper is organized as follows. Section 2 describes the monitoring site and measurement instruments used in this study. Section 3 presents the procedures used to classify the aerosol and describes the optical properties of aerosol transported to Korea, using the results obtained from the integrated monitoring of 
98 atmospheric aerosols. Finally, we discuss our results and the values for aerosol type 99 classification in this study in Section 3.

100

101

\section{Measurements}

102 High $\mathrm{PM}_{10}$ levels $\left(>100 \mu \mathrm{g} \mathrm{m}^{-3}\right)$ were observed in Gwangju, South Korea between April 1035 and 12 2009. Integrated monitoring of atmospheric aerosols was performed using the 104 AERONET sun/sky radiometer and depolarization lidar at the Gwangju Institute of Science 105 and Technology (GIST), Gwangju $\left(35.10^{\circ} \mathrm{N}, 126.53^{\circ} \mathrm{E}\right)$, and using the Moderate Resolution 106 Imaging Spectroradiometer (MODIS) on board the Terra and Aqua satellites.

\subsection{Sun/sky radiometer}

The AERONET sun/sky radiometer was operated at GIST. Column-integrated spectrally resolved aerosol measurements and sky-bright observations (almucantar measurements) were performed with the polarized-version of the CIMEL 381-1 automatic tacking sun/sky radiometer (Holben et al., 1998). The sun/sky radiometer measurements incorporated the radiances from four spectral channels at wavelengths of 440, 675, 870, and $1020 \mathrm{~nm}$. Direct sun radiation at 15-minute intervals and sky radiation at 1-hour intervals were also observed. The sun/sky radiometer measurements were used to retrieve $\tau$, the absorption Ångström exponents (AAE), the complex refractive index, and the size distribution via the AERONET algorithm. The Ångström exponents (AE) were retrieved directly from the optical depth measurements. Detailed information on the cloud-screening and inversion data retrieval algorithm can be found in Dubovik and King (2000). In the present study, we used 
120 AERONET level 2.0 data (quality assured), which can be downloaded from the AERONET 121 website (http://aeronet.gsfc.nasa.gov).

122 The linear particle depolarization ratios strongly depend on particle shape. We calculated 123 the depolarization ratio from the sun/sky radiometer data using the kernel look-up tables as 124 described by Dubovik et al. (2006). Linear particle depolarization ratios $\left(\boldsymbol{\delta}_{\text {sp }}\right)$ at the four 125 wavelengths $(440,675,870$, and $1020 \mathrm{~nm})$ were derived from the sun/sky radiometer 126 measurements to identify non-sphericity within the observed aerosol. Detailed retrieval 127 method is described by Lee et al. (2010c) as follows.

The elements $F_{11}(\lambda)$ and $F_{22}(\lambda)$ of the so-called Müller scattering matrices (Bohren et al., 1983) are computed from the retrieved complex refractive index and particle size distributions. The two parameters strongly depend on the angular and spectral distribution of the radiative intensity, which is measured with the AEROENT instrument (Dubovik et al., 2006). For unpolarized incident light, $F_{11}(\lambda)$ is proportional to the flux of the scattered light

(Volten et al., 2001). Another input parameter that is needed for the retrieval of the linear particle depolarization ratio is the so-called aspect ratio distribution. The aspect ratio indicates the ratio of particle's longest axis to its shortest axis. In case of prolate particles, its polar diameter is greater than the equatorial diameter in contrast to oblate particles. The aspect ratio distribution is kept to a fixed distribution in the AERONET model, since scattering elements are nearly equivalent for all spheroid mixtures (Dubovik et al., 2006).

From the ratio of the elements $F_{11}(\lambda)$ and $F_{22}(\lambda)$ at the scattering angle $180^{\circ}$ the linear particle depolarization ratio $\delta_{p}(\lambda)$ can be computed as (Dubovik et al., 2006)

141

$$
\delta_{p}(\lambda)=\frac{1-F_{22}\left(\lambda, 180^{\circ}\right) / F_{11}\left(\lambda, 180^{\circ}\right)}{1+F_{22}\left(\lambda, 180^{\circ}\right) / F_{11}\left(\lambda, 180^{\circ}\right)} \times 100(\%)
$$


143

144

145

146

147

148

149

150

151

152

153

154

155

156

157

158

159

160

161

162

163

164

165

\subsection{Depolarization lidar}

The depolarization lidar system was used to monitor the vertical distribution of observed aerosols during the high- $\mathrm{PM}_{10}$ levels. Measurements with the GIST multiwavelength Raman LIDAR system were carried out at the same site as that of the AERONET sun/sky radiometer. For a detailed description of the multiwavelength aerosol lidar system, the methodology used to analyze the optical data, and uncertainty analysis, see Noh et al. $(2007,2008,2009)$. The vertical distribution of observed aerosols can be obtained using the aerosol backscatter coefficient. The parallel- and perpendicular-polarized signal components (with respect to the plane of polarization of the emitted laser beam) were measured at $532 \mathrm{~nm}$ to derive the aerosol backscatter coefficient and the linear volume depolarization ratio $(\boldsymbol{\delta})$. The linear particle depolarization ratio $\left(\boldsymbol{\delta}_{\mathbf{p}}\right)$ differs from $\boldsymbol{\delta}$ as it depends on the concentration of particles in relation to the concentration of air molecules. $\boldsymbol{\delta}_{\mathbf{p}}$ is calculated as an intensive parameter and can be used to qualitatively describe the average morphology of the measured aerosol particles. We applied the equation to retrieve the $\boldsymbol{\delta}_{\mathbf{p}}$, as proposed by Noh et al. (2013). The value of $\boldsymbol{\delta}_{\mathbf{p}}$ is $0 \%$ for an ideal spherical particle. In the presence of dust particles, the depolarization ratio increases up to $30 \%$, depending on the amount of dust particles in the aerosol plume (Shimizu et al., 2004; Noh et al., 2012, 2014; Shin et al., 2014).

The $\mathrm{PM}_{10}$ concentrations were measured at the Gwangju Local Meteorological Administration building, $5 \mathrm{~km}$ from the observation site.

\subsection{Satellite data}

Satellite observations such as AVHRR, SeaWIFS, MODIS, MISR, and GOCI have previously been used to monitor air quality and estimate the location and extent of aerosols 
166 (Rao et al., 1989; Gordon and Wang, 1994; Kaufman et al., 1997; Lee et al., 2010a). A dataset

167 collected by MODIS was used during a period when it was performing the integrated 168 monitoring of atmospheric aerosol. The spatial distribution of Aerosol Optical Depth (AOD $169(\boldsymbol{\tau}))$ at $550 \mathrm{~nm}$ from MODIS and the MODIS SaTellite Aerosol Retrieval (MSTAR) algorithm, 170 as reported by Lee et al. (2010b), were used to determine the origin and track the long-range 171 transport of atmospheric aerosol.

\subsection{Model simulations for Backward Trajectories and Pollution emission}

The Hybrid Single Particle Lagrangian Integrated Trajectory (HYSPLIT) model

175 (Draxler and Rolph, 2003) was used to generate 5-day backward trajectories for air masses 176 arriving over the measurement site at the altitude of the aerosol layers observed by the 177 depolarization lidar. These trajectories allowed us to track the origin of the aerosol layers and 178 their transport pathway. The European Centre for Medium-range Weather Forecast (ECMWF) 179 provides aerosol reanalysis data as part of the MACC project. These data assimilate the 180 satellite data (e.g., the AOD ( $\boldsymbol{\tau})$ retrieved by MODIS) into the global model. Thus, the 181 reanalysis data are considered as comparably reliable data because corrections for the model 182 departure from observational data were performed during the assimilation (Bellouin et al., 183 2013). This reanalysis provides information on pollution caused by the emission of various 184 aerosols, as well as chemically reactive gases and greenhouse gases. We used the $\tau$ values of 185 dust particles, black carbon, and organic matter from the MACC reanalysis data to determine 186 the intensity of pollution along the transport pathway and to estimate the characteristics of 187 atmospheric aerosols. 


\section{Results}

190

191

192

193

194

195

196

197

198

199

200

201

202

203

204

205

206

207

208

209

210

211

\subsection{High-PM 10 episode, April 9-12 2009}

Hourly averaged surface $\mathrm{PM}_{10}$ concentrations were obtained using a beta gauge between 00:00 local time (LT) April 5 and 24:00 LT on April 12 are plotted in Fig. 1. The $\mathrm{PM}_{10}$ concentration begins to increase above the South Korea's 24-hour $\mathrm{PM}_{10}$ standard $\left(100 \mu \mathrm{g} \mathrm{m}^{-3}\right)$ from April 5 (15:00 LT), and these high values were continuously observed until April 12 (12:00 LT). The $\mathrm{PM}_{10}$ concentrations only fell below this level on April 7 (15:00 - 21:00 LT) and April 9 (14:00 - 17:00 LT).

The values of $\boldsymbol{\tau}_{\mathbf{5 0 0}}(\mathrm{AOD}$ at $500 \mathrm{~nm}$ ), AE at $440-870 \mathrm{~nm}$, and AAE at $440-870 \mathrm{~nm}$ measured with the AERONET sun/sky radiometer and $\boldsymbol{\tau}_{\mathbf{5 5 0}}(\mathrm{AOD}$ at $550 \mathrm{~nm}$ ) retrieved by MODIS are shown in Fig. 1 and Table 1. The temporal variations in $\boldsymbol{\tau}_{\mathbf{5 0 0}}$ and $\boldsymbol{\tau}_{\mathbf{5 5 0}}$ are similar to those of $\mathrm{PM}_{10}$ levels. Values of $\boldsymbol{\tau}_{\mathbf{5 0 0}}$ and $\boldsymbol{\tau}_{\mathbf{5 5 0}}$ increased when the $\mathrm{PM}_{10}$ concentration increased, whereas the lower values of $\boldsymbol{\tau}_{\mathbf{5 0 0}}$ and $\boldsymbol{\tau}_{\mathbf{5 5 0}}$ were measured as the concentration decreased in most cases. Differences in the values of the AEs were recorded during the high$\mathrm{PM}_{10}$ episode. The AE values measured during April 6 - 82009 were in the range 1.24 - 1.38 (average $=1.31 \pm 0.06$ ), and thus considerably lower than those recorded during April 9 - 11 $2009(1.42-1.53$, average $=1.47 \pm 0.04)$. These differences suggest that the aerosol layers observed from April 5 to 8 contained a higher concentration of large aerosol particles when compared with the average particle size in the aerosol layer observed from April 9 to 11. This result is possibly related to differences in the types and sources of the atmospheric aerosols.

The AAEs measured during April 6 - 82009 were in the range $0.62-1.36$ (average $=$ $1.03 \pm 0.20)$ and thus were similar to those recorded during April 9 - 112009 (0.85 - 1.59, average $=1.06 \pm 0.21)$. Russell et al. (2010) showed that AAE is correlated with aerosol 
212 composition or type, and reported AAE values near 1 for AERONET-measured aerosol 213 columns dominated by urban-industrial aerosol. Although the aerosol size was different 214 between the two periods, as inferred from AE values, the main aerosol type using the AAE 215 can be estimated. However, a more detailed analysis is required to determine which 216 atmospheric aerosol types caused the high $\mathrm{PM}_{10}$ levels during early April of 2009.

217 Figure 2 shows time-height cross-sections of the aerosol backscatter coefficient and the 218 volume depolarization ratio $(\boldsymbol{\delta})$ derived from continuous depolarization ratio lidar 219 measurements between April 5 and 12 2009. No observations were made from 12:00 LT on 220 April 8 to 00:00 LT on April 9 because of precipitation. Figure 2(a) shows the presence of 221 atmospheric aerosol that was detected mostly within the planetary boundary layer $(1-2 \mathrm{~km}$ 222 altitude) during the observation periods. The significant atmospheric aerosol layers were 223 defined using their relatively high backscatter coefficients at low altitudes. However, the 224 backscatter coefficients shown in Fig. 2(a) only provide qualitative information and the 225 vertical distribution of atmospheric aerosol. A preliminary classification of the types of 226 atmospheric aerosol observed during this period was made using the $\boldsymbol{\delta}$ values shown in Fig. $2272(b) . \delta$ is a reliable indicator of particle shape and can be used to distinguish between non228 spherical and spherical particles (Shimizu et al., 2004, Noh et al., 2012, Shin et al., 2015). In 229 Fig. 2(b), the $\boldsymbol{\delta}$ values begin to increase in the layer between 1 and $2 \mathrm{~km}$ on April 5 2009. The 230 values of $\boldsymbol{\delta}$ greater than $10 \%$ suggest the inflow of atmospheric aerosol containing dust 231 particles. The higher $\boldsymbol{\delta}$ values (ca. $13 \%$ ) detected from April 6 to 8 indicate that the 232 atmospheric aerosol over Korea contained a higher amount of dust particles than on other 233 observation days. In contrast, the $\boldsymbol{\delta}$ value in the layer around $2 \mathrm{~km}$ decreased from April 9 234 onwards. This might point to the inflow of another type of atmospheric aerosol at higher 235 altitudes, although atmospheric aerosols with relatively high depolarization ratios ( $>8 \%)$ 
236 were still detected at lower altitudes.

\subsection{Classification of aerosol source}

239

Figure 3 shows the results from the HYSPLIT backward trajectories and the distribution of $\tau$ at $550 \mathrm{~nm}$ for dust, black carbon, and organic matter obtained from the MACC model and calculated using ECMWF reanalysis data. The distribution of the aerosol optical depth derived from MODIS is also shown in Fig. 3.

The consistently high values of $\boldsymbol{\tau}$ detected by MODIS correspond with the high aerosol loading for the observation period. The heights of the aerosol layers were determined from the lidar measurements; i.e., the aerosol layers with heights that correspond to increased backscatter coefficients and $\delta$ values, for the calculation of the HYSPLIT model. The HYSPLIT model shows different transport pathways and source regions of the aerosol layer observed on each measurement day. The air masses were transported to the observation site from either the west or northwest of the monitoring site (eastern and northeast China, respectively) over April $6-8$, as shown in Fig. 3 (a1 - c1). In contrast, the backward trajectories for arrival heights of 1600 and $2000 \mathrm{~m}$ on April 9 differ from the air mass movement patterns for April 6 - 8. On April 9, the air masses that passed over the monitoring site at 1600 and $2000 \mathrm{~m}$ were more likely to have arrived from the north via North Korea, whereas the air masses at lower altitudes $(800$ and $1200 \mathrm{~m})$ were transported from the west/northwest regions. The changes in the air mass movement patterns were more obvious on April 10 and 11. The air masses that arrived at the observation site at higher altitudes 257 (1600 and $2000 \mathrm{~m}$ ) on April 10 and 11 had passed over Siberia and North Korea. However, 258 the air masses that passed over the observation site at lower altitudes on April 10 and 11 were 
259 transported from desert regions and passed over eastern and northeast China. The aerosols 260 observed on April 12 seem to have been generated from local sources. We consider that the 261 aerosol load during the high- $\mathrm{PM}_{10}$ episodes was caused by the transportation of various 262 aerosols from different source regions.

263 The differing source regions and origins of each transported aerosol result in different 264 aerosol compositions. Those air masses with a desert origin might consist primarily of dust 265 particles, whereas those transported over densely populated/highly industrialized areas are 266 likely to include anthropogenic pollutants. The smoke particles, possibly derived from 267 biomass/forest burning in Siberia and North Korea, are more likely to contain black carbon 268 and organic matter. The distribution of $\boldsymbol{\tau}$ for dust, black carbon, and organic matter computed 269 by the MACC model using the ECMWF reanalysis data were used to estimate the distribution 270 of the various aerosols transported to Korea, as shown Fig. 3 (a3 - g5). The dust particles 271 emitted from the desert regions of Inner Mongolia were transported across China and affected 272 Korea during April 7 - 9. The model values of $\boldsymbol{\tau}$ for the dust over Korea on April 7 - 9 are 273 significantly higher than for the other dates during the monitoring period. The $\tau$ of black 274 carbon that possibly originated from industrial regions of China was also significantly higher 275 on April 7 - 9. On the other hand, the $\boldsymbol{\tau}$ of black carbon and organic matter over Siberia and 276 on the transport pathway of the air masses increased from April 9 onwards. Figure 4 shows 277 the accumulated fire spots obtained from the MODIS thermal anomalies/fire product 278 (Kaufman et al., 1998) for April 9 - 12 2009. Although a few fire spots were detected in 279 northeast China, most were in northeast Siberia and North Korea. This suggests that aerosols 280 observed on April 9 - 11 were affected by the transport of smoke from Siberia. As a result, the $281 \tau$ of black carbon and organic matter in Siberia on these observation days increased. On the 282 basis of the distribution of $\boldsymbol{\tau}$ for various aerosols obtained from the MACC model, and the 
transport pathway of aerosol retrieved from the HYSPLIT model, we conclude that the types 284 of aerosol that generated the high- $\mathrm{PM}_{10}$ event were dust particles, anthropogenic pollutants, 285 and smoke particles. Moreover, the influence of these aerosols on high aerosol loading over

\subsection{Depolarization ratio}

Lidar-derived $\boldsymbol{\delta}_{\mathbf{p}}$ values can be used to estimate the amount of mixed dust in aerosol plumes (Shimizu et al., 2004; Tesche et al., 2011; Noh et al., 2012; 2014). However, sun/sky radiometer-derived $\boldsymbol{\delta}_{\text {sp }}$ values have previously been applied only to the study of Saharan dust (Müller et al., 2010). Figure 5 shows $\boldsymbol{\delta}_{\text {sp }}$ values at four wavelengths derived from the sun/sky radiometer data, and the column-integrated $\boldsymbol{\delta}_{\mathbf{p}}$ at $532 \mathrm{~nm}$ derived from the lidar system. The correlation of $\boldsymbol{\delta}_{\mathbf{p}}$ between lidar and sun/sky radiometer is shown in Figure 6 . The depolarization ratios from the two instruments are in relatively good agreement throughout the observation period. However, the $\boldsymbol{\delta}_{\mathbf{p}}$ by lidar in many cases was lower than the AERONET sun/sky radiometer-derived $\boldsymbol{\delta}_{\text {sp. }}$. The vertical distribution of $\boldsymbol{\delta}$ in Fig. 2 (b) shows that $\boldsymbol{\delta}$ decreases above an altitude of $0.5 \mathrm{~km}$ from April 12 (09:00 LT). However, we must remember that the lidar-derived data do not take account of the optical properties of the aerosols below $0.5 \mathrm{~km}$. The incomplete overlap between the laser beam and the field of view of the receiver telescope does not allow for a reliable retrieval of lidar profiles in this altitude range (Noh et al., 2013). Considering the high $\boldsymbol{\delta}_{\text {sp }}$ and $\boldsymbol{\tau}$ values obtained from the sun/sky radiometer data, it seems that the dust particles inducing high $\boldsymbol{\delta}$ existed below the lidar overlap height. 
306 The value of $\boldsymbol{\delta}_{\mathbf{s p}}$ at $440 \mathrm{~nm}$ was greater than that at the other wavelengths in most cases.

307 Müller et al. (2010) reported that the values increase with wavelength for the pure dust cases.

308 However, $\boldsymbol{\delta}_{\text {sp }}$ decreases with wavelength for mixed dust cases (Lee et al., 2010c). From these

309 results, the aerosols in this study can be interpreted as mixed dust. However, the daily

310 average values listed in Table 1 show clear differences over time. The $\boldsymbol{\delta}_{\text {sp }}$ values at $440 \mathrm{~nm}$

311 between April 5 and 8 (12.5 - 14.2\%) were higher than them between April 9 and 11 (5.8 -

$3129.8 \%$ ). The depolarization ratios of individual aerosol types have been reported previously;

313 e.g., 10 - $20 \%$ for polluted dust (Shimizu et al., 2004; Tesche et al., 2011; Burton et al., 2012;

314 Shin et al., 2013), 30 - 35 \% for pure dust (Murayama et al., 2004; Freudenthaler et al., 2009),

$3154-9 \%$ for smoke (Murayama et al., 2004), and $<5 \%$ for pollution particles (Yoon et al.,

316 2010). If we consider only daily average $\boldsymbol{\delta}_{\text {sp }}$ values, the aerosol observed over the periods

317 April 5 - 8 and 9 - 11 can be categorized as polluted dust and smoke particles, respectively.

318 However, the data in Fig. 5 (e and f) show relatively high $\boldsymbol{\delta}_{\text {sp }}$ values of $8.3-11.6 \%$ in the

319 morning on April 9 and 10. Lidar-derived $\boldsymbol{\delta}_{\mathbf{p}}$ also shows values that are $1-3 \%$ higher in the

320 morning than afternoon in Fig. 2 (b). The distribution of dust calculated using the MACC

321 model (Fig. 3) shows that the dust particles are continuously distributed around South Korea.

322 The relatively high values of $\boldsymbol{\delta}_{\text {sp }}$ in the morning on April 9 and 10 is likely to have been

323 caused by dust particles. The relatively high $\boldsymbol{\delta}_{\text {sp }}$ values on April 12 are also likely to have 324 been affected by dust particles.

\subsection{Optical/microphysical properties}

Figure 7 shows the daily average value of the real and imaginary parts of the refractive 328 index at 440, 675, 875, and $1020 \mathrm{~nm}$ obtained from the AERONET sun/sky radiometer 329 between April 5 and 12. 
The real part of the refractive index describes the scattering properties, whereas the

331

332

333

334

335 imaginary part describes the absorption properties of the particles (Barber et al., 1999). Differences in the values of the refractive index were found for the different aerosol transport pathways on each measurement day. The values of the real part of the refractive index measured on April 7 and 8 were $1.47 \pm 0.06$ and $1.49 \pm 0.03$, respectively, at $440 \mathrm{~nm}$. These values are larger, and less variable, than those measured between April 9 and 12, which were $1.41 \pm 0.03$ to $1.46 \pm 0.04,1.44 \pm 0.03$ to $1.47 \pm 0.03,1.45 \pm 0.03$ to $1.48 \pm 0.02$, and $1.45 \pm$ 0.02 to $1.47 \pm 0.02$ at $440,675,870$, and $1020 \mathrm{~nm}$, respectively.

Several previous studies have reported the real part of the refractive index for various aerosols. For example, Dubovik et al. (2002) used AERONET sun/sky radiometer data and observed the real part of refractive index values of $1.55 \pm 0.03$ to $1.56 \pm 0.03$ for desert dust, of 1.47 and 1.52 for smoke derived from biomass burning in the Amazonian forest region and in the South American Cerrado, respectively, and lower values for urban/industrial aerosols. In this study the real part of refractive index values ranged from 1.39 to 1.47. Noh et al. (2009, 2011) reported values for smoke aerosols from Siberia and northern China, and urban haze from northeast China, of $1.41 \pm 0.03$ to $1.42 \pm 0.02$ and $1.44 \pm 0.03$ to $1.44 \pm 0.05$, respectively.

The value of the imaginary part of the refractive index, which represents the lightabsorption properties of the aerosol particles, tended to vary according to the aerosol source region. Lower values for the imaginary part were measured on April 7 and 8 in the ranges $0.008-0.009,0.008-0.007,0.008-0.007$, and $0.009-0.007$ at 440, 675, 870, and $1020 \mathrm{~nm}$, respectively. These values are higher than the values for the imaginary part of desert dust reported by Dubovik et al. (2002) of $0.0025-0.0029,0.0013-0.0014,0.001$, and 0.001 at $440,670,870$, and $1020 \mathrm{~nm}$, respectively. The values of the imaginary part of the refractive 
354 index increased when the source and transport pathway of the aerosol changed, and were 355 higher between April 9 and 11 (by about 0.01) than on April 7 and 8. These differences 356 between the real and imaginary parts of the refractive index indicate that the aerosol types 357 changed during the high- $\mathrm{PM}_{10}$ episode. However, it is difficult to classify the aerosol types 358 using only the refractive index data obtained during the high- $\mathrm{PM}_{10}$ episode.

359 Figure 8 shows the particle volume size distributions observed at the same time as $\tau$ in 360 Fig. 1. The distribution is bimodal in all cases, but the dominant particle size changes over 361 the monitoring period. A fine-mode dominance is evident on April 5, the size distribution on 362 April 7 and 8 shows sub-equal amounts of fine and coarse particles, and finer material is 363 again dominant during April 9 - 12. The presence of larger particles on April 7 and 8 suggests 364 that dust particles were transported into the region on these days. A significant fine fraction $365(<0.5 \mu \mathrm{m})$ is also apparent in the size distribution, which we interpret to indicate that the 366 aerosol particles transported on April 7 and 8 were a mixture of dust and anthropogenic 367 particles. However, the proportion of fine particles increased from April 9 onwards. The 368 proportion of finer particles was much greater on April 10 and 11 (Fig. 8), possibly related to 369 the dominance of smoke particles that originated from Siberia and North Korea, as explained 370 previously.

Figure 9 shows daily averaged single scattering albedo (SSA) at four wavelengths (440, 372675,870 , and $1020 \mathrm{~nm}$ ) from 5 to 12 April 2009. The spectral SSA behavior can be utilized 373 for main aerosol type classification (Dubovik et al., 2002; Eck et al., 2005; 2010; Giles et al., 374 2012). Increasing spectral SSA behavior is observed for dust particle. In contrast, 375 urban/industrial or biomass burning aerosol shows the decreasing spectral SSA behavior (Eck 376 et al., 2005). In mixed cases, these spectral behaviors are lessened (Eck et al., 2005; 2010; 377 Giles et al., 2012). Since the mixed plume of dust and anthropogenic/biomass burning 
378 particles was observed during research period, clear pattern of spectral SSA behavior for 379 aerosol type classification was not shown in Figure 9. However, Increase of SSA between 380 440 and $675 \mathrm{~nm}$ was shown on 7 and 8 April 2009 at the dust dominant cases. Spectral SSA

\section{Summary and conclusions}

In this study, satellite, lidar, and AERONET sun/sky radiometer data, in combination with data from the HYSPLIT and MACC models, were analyzed to determine the sources of observed atmospheric aerosol. We found that high $\mathrm{PM}_{10}$ levels were affected differently by dust, and anthropogenic and smoke aerosols.

The sun/sky radiometer-derived $\boldsymbol{\delta}_{\mathbf{s p}}$ values are similar to the lidar-derived values, and these values highlight the effect of dust particles on aerosol observation, as the depolarization ratio is directly related to the non-sphericity of particles. From these values, we can infer that dust particles were continuously present during the high- $\mathrm{PM}_{10}$ episode, but were most prominent during April 5 - 8 based on the relatively elevated $\boldsymbol{\delta}_{\text {sp }}$ values of between $12.5 \%$ and $14.2 \%$. And the aerosol plume transported from the west between at that time. In contrast, lower particle depolarization ratios $(5.8$ - 9.8\%) were detected when the aerosol plume was transported from north in other observation days.

The optical and microphysical properties of atmospheric aerosol retrieved from the AERONET sun/sky radiometer data during the high- $\mathrm{PM}_{10}$ episode showed similar trend with $\boldsymbol{\delta}_{\text {sp }}$ during observation period. The atmospheric aerosol transported from the west showed 
401 higher values in the real part of the refractive index, lower values in the imaginary part of the 402 refractive index, and a high proportion of coarser particles. In contrast, the atmospheric 403 aerosol transported from the north showed lower values in the real part of the refractive index, 404 higher values in the imaginary part of the refractive index, and a greater proportion of finer 405 particles. However, the use of these parameters alone is generally insufficient to clarify the 406 effect of dust particles on the mixed aerosol plumes. We can clearly classify the aerosol type 407 and the degree of mixing among various aerosols when depolarization ratio is analyzed with 408 other optical and microphysical parameters.

409 If $\boldsymbol{\delta}_{\text {sp }}$ values are combined with other optical and microphysical parameters retrieved 410 from AERONET sun/sky radiometer data, it is possible to estimate the aerosol characteristics 411 and degree of mixing of dust particles without the support of other analytical techniques.

\section{Acknowledgements}

414 This work was funded by the Korea Meteorological Administration Research and 415 Development Program under Grant KMIPA2015-6150. This research was also supported by 416 the International Environmental Research Center (IERC)

\section{References}

Barber, and Thomas A., 1999: Control of particulate matter contamination in healthcare manufacturing. 1st ed., Englewood: Interpharm Press, 363-408. 
424 forcing from the MACC re-analysis. Atmospheric Chemistry and Physics, 13(4), 2045-2062.

426 Bohren, C. F., \& Huffman, D. R., 1983: Absorption and scattering of light by small particles. 427 Wiley, New York, 541p.

Burton, S. P., Ferrare, R. A., Hostetler, C. A., Hair, J. W., Rogers, R. R., Obland, M. D., Butler, airborne High Spectral Resolution Lidar measurements-methodology and examples. Atmospheric Measurement Techniques, 5(1), 73-98.

Draxler, R. R., and Rolph, G. D., 2003: HYSPLIT (HYbrid Single-Particle Lagrangian Integrated Trajectory) model access via NOAA ARL READY website (http://www. arl. noaa. gov/ready/hysplit4. html). NOAA Air Resources Laboratory, Silver Spring.

Dubovik, Oleg, and Michael D. King., 2000: A flexible inversion algorithm for retrieval of aerosol optical properties from Sun and sky radiance measurements. Journal of Geophysical Research: Atmospheres (1984-2012), 105(D16), 20673-20696.

Dubovik, O., Holben, B., Eck, T. F., Smirnov, A., Kaufman, Y. J., King, M. D., Tanre D., and Slutsker, I., 2002: Variability of absorption and optical properties of key aerosol types observed in worldwide locations. Journal of the atmospheric sciences, 59(3), 590-608.

Dubovik, O., Sinyuk, A., Lapyonok, T., Sinyuk, A., Mishchenko, M. I., Yang, P., Eck, T. F., Volten, H., Munoz, O., Veihelmann, B., van der Zander, W. J., Sorokin, M., and Slutsker, I., 2006: Application of light scattering by spheroids for accounting for particle non-sphericity in remote sensing of desert dust. J. Geophys. Res., 111, D11208, doi:10.1029/2005JD006619. 
451 Eck, T. F., Holben, B. N., Dubovik, O., Smirnov, A., Goloub, P., Chen, H. B., Chatenet, B., 452 Gomes, L., Zhang, X.-Y., Tsay, S.-C., Ji, Q., Giles, D., and Slutsker, I., 2005: Columnar 453 aerosol optical properties at AERONET sites in central eastern Asia and aerosol transport to 454 the tropical mid-Pacific. J. Geophys. Res., 110, D06202, doi:10.1029/2004JD005274.

455

456

Eck, T. F., Holben, B. N., Sinyuk, A., Pinker, R. T., Goloub, P., Chen, H., Chatenet, B., Li, Z., 457 Singh, R. P., Tripathi, S. N., Reid, J. S., Giles, D. M., Dubovik, O., O’Neill, N. T., Smirnov, 458 A., Wang, P., and Xia, X., 2010: Climatological aspects of the optical properties of 459 fine/coarse mode aerosol mixtures, J. Geophys. Res., 115, D19205, 460 doi:10.1029/2010JD014002.

Freudenthaler, V., Esselborn, M., Wiegner, M., Heese, B., Tesche, M., Ansmann, A., Müller, dust during SAMUM 2006. Tellus B, 61(1), 165-179.

Giles, D. M., B. N. Holben, T. F. Eck, A. Sinyuk, A. Smirnov, I. Slutsker, R. R. Dickerson, A. M. Thompson, and J. S. Schafer, 2012: An analysis of AERONET aerosol absorption properties and classifications representative of aerosol source regions, J. Geophys. Res., 117, D17203, doi:10.1029/2012JD018127

Gordon, H. R. and Wang, M., 1994: Retrieval of water-leaving radiance and aerosol optical 473 thickness over the oceans with Sea-WiFS: A preliminary algorithm. Appl. Optics, 33, 443$474 \quad 452$. 
479 Holben, B.N., Eck, T.F., Slutsker, I., Tanre, D., Buis, J.P., Setzer, A., Vermote, E., Reagan, 480 J.A., Kaufman, Y.J., Nakajima, T., Lavenu, F., Jankowiak, I., and Smirnov, A., 1998: 481 AERONET - A federated instrument network and data archive for aerosol characterization. 482 Remote Sens. Environ., 66(1), 1-16.

483

Jung, J., and Kim, Y. J., 2011: Tracking sources of severe haze episodes and their 485 physicochemical and hygroscopic properties under Asian continental outflow: Long-range 486 transport pollution, postharvest biomass burning, and Asian dust. Journal of Geophysical Research: Atmospheres (1984-2012), 116(D2).

Kaufman, Y. J., Wald, A. E., Remer, L. A., Gao, B. C., Li, R.-R., and Flynn, L., 1997: The 490 MODIS 2.1-mm channel correlation with visible reflectance for use in remote sensing of aerosol. IEEE T. Geosci. Remote, 35, 1286-1298.

Kaufman, Y. J., Justice, C. O., Flynn, L. P., Kendall, J. D., Prins, E. M., Giglio, L., Ward, D. E. Menzel W. P., and Setzer, A. W., 1998: Potential global fire monitoring from EOS-MODIS. 495 Journal of Geophysical Research: Atmospheres (1984-2012), 103(D24), 32215-32238.

496

Kim, K. W., Kim, Y. J., and Bang, S. Y., 2008: Summer time haze characteristics of the urban 498 atmosphere of Gwangju and the rural atmosphere of Anmyon, Korea. Environmental monitoring and assessment, 141(1-3), 189-199.

500

501

Lasserre, F., Cautenet, G., Bouet, C., Dong, X., Kim, Y. J., Sugimoto, N., Matsui, I., and 502 Shimizu, A., 2008: A model tool for assessing real-time mixing of mineral and anthropogenic 503 pollutants in East Asia: a case study of April 2005. Atmospheric Chemistry and Physics, 8(13), $504 \quad 3603-3622$. 
506 Lee, J., Kim, J., Song, C. H., Ryu, J. H., Ahn, Y. H., and Song, C. K., 2010a: Algorithm for

507 retrieval of aerosol optical properties over the ocean from the Geostationary Ocean Color 508 Imager. Remote Sensing of Environment, 114(5), 1077-1088.

509

510 Lee, K. H., and Y. J. Kim., 2010b: Satellite remote sensing of Asian aerosols: a case study of 511 clean, polluted, and Asian dust storm days. Atmospheric Measurement Techniques, 3(6), 512 1771-1784.

513

Lee, K. H., Muller, D., Noh, Y. M., Shin, S. K., and Shin, D. H., 2010c: Depolarization ratio 515 retrievals using AERONET sun photometer data. Journal of the Optical Society of Korea, 516 14(3), 178-184.

517

Lee, K. H., Kim, J. E., Kim, Y. J., Kim, J., and von Hoyningen-Huene, W., 2005: Impact of the smoke aerosol from Russian forest fires on the atmospheric environment over Korea during May 2003. Atmospheric Environment, 39(1), 85-99.

521

Moon, K. J., Han, J. S., Ghim, Y. S., and Kim, Y. J., 2008: Source apportionment of fine 523 carbonaceous particles by positive matrix factorization at Gosan background site in East Asia. 524 Environment international, 34(5), 654-664.

526 Murayama, T., Müller, D., Wada, K., Shimizu, A., Sekiguchi, M., and Tsukamoto, T., 2004: 527 Characterization of Asian dust and Siberian smoke with multi-wavelength Raman lidar over 528 Tokyo, Japan in spring 2003. Geophysical Research Letters, 31(23).

530 Müller, D., Ansmann, A., Freudenthaler, V., Kandler, K., Toledano, C., Hiebsch, Gasteiger, J., 531 Esselborn, M., Tesche, M., Heese, B., Althausen, D., Weinzierl, B., Petzold, A., and von 532 Hoyningen-Huene, W., 2010: Mineral dust observed with AERONET Sun photometer, 
533 Raman lidar, and in situ instruments during SAMUM 2006: Shape-dependent particle 534 properties. J. Geophys. Res., 115, D11207, doi:10.1029/2009JD012523.

535

536 Noh, Y. M., Kim, Y. J., Choi, B. C., and Murayama, T., 2007: Aerosol lidar ratio 537 characteristics measured by a multi-wavelength Raman lidar system at Anmyeon Island. 538 Korea. Atmos. Res., 86, 76-87.

539

Noh, Y. M., Kim, Y. J., and Müller, D. 2008: Seasonal characteristics of lidar ratios measured with a Raman lidar at Gwangju, Korea in spring and autumn. Atmos. Environ., 42, 22085422224.

543

544 Noh, Y. M., Müller, D., Shin, D. H., Lee, H., Jung, J. S., Lee, K. H., Cribb, M., Li, Z., and 545 Kim, Y. J., 2009: Optical and microphysical properties of severe haze and smoke aerosol 546 measured by integrated remote sensing techniques in Gwangju, Korea. Atmospheric 547 Environment, 43(4), 879-888.

548

Noh, Y. M., Müller, D., Mattis, I., Lee, H., and Kim, Y. J., 2011: Vertically resolved light550 absorption characteristics and the influence of relative humidity on particle properties: Multiwavelength Raman lidar observations of East Asian aerosol types over Korea. Journal of Geophysical Research, 116: D06206,doi: 10.1029/2010JD014873.

Noh, Y. M., Müller, D., Lee, H., Lee, K., Kim, K., Shin, S., and Kim, Y. J., 2012: Estimation 555 of radiative forcing by the dust and non-dust content in mixed East Asian pollution plumes on 556 the basis of depolarization ratios measured with lidar. Atmospheric Environment, 61, 221-231. 
560 lower troposphere using LIDAR. Atmospheric Chemistry and Physics, 13(15), 7619-7629.

561

562 Noh, Y. M., 2014: Single-scattering albedo profiling of mixed Asian dust plumes with 563 multiwavelength Raman lidar. Atmospheric Environment, 95, 305-317.

564

565

Park, S. S., Kim, Y. J., Cho, S. Y., and Kim, S. J., 2007: Characterization of $\mathrm{PM}_{2.5}$ aerosols

566

dominated by local pollution and Asian dust observed at an urban site in Korea during aerosol

567 characterization experiments (ACE)-Asia Project. Journal of the Air \& Waste Management 568 Association, 57(4), 434-443.

569

Rao, C. R. N., McClain, E. P., and Stowe, L. L., 1989: Remote sensing of aerosols over the oceans using AVHRR data theory, practice, and applications. Int. J. Remote Sens., 10(4-5), $743-749$.

573

Russell, P. B., Bergstrom, R. W., Shinozuka, Y., Clarke, A. D., DeCarlo, P. F., Jimenez, J. L.,

Redemann, J., Dubovik O., and Strawa, A., 2010: Absorption Angstrom Exponent in AERONET and related data as an indicator of aerosol composition. Atmospheric Chemistry and Physics, 10(3), 1155-1169.

Sahu, L. K., Kondo, Y., Miyazaki, Y., Kuwata, M., Koike, M., Takegawa, N., Tanimoto, H., Matsueda, H., Yoon, S. C., and Kim, Y. J., 2009: Anthropogenic aerosols observed in Asian continental outflow at Jeju Island, Korea, in spring 2005. J. Geophys. Res., 114, D03301, doi:10.1029/2008JD010306.

Shimizu, A., Sugimoto, N., Matsui, I., Arao, K., Uno, I., Murayama, T., Kagawa, N., Aoki, K., 585 Uchiyama, A., and Yamazaki, A., 2004: Continuous observations of Asian dust and other 586 aerosols by polarization lidars in China and Japan during ACE-Asia. J. Geophys. Res. 109, 
doi:10.1029/2002JD003253.

588

Shin, S., Müller, D., Kim, Y. J., Tatarov, B., Shin, D., Seifert, P., and Noh, Y. M., 2013: The 590 retrieval of the Asian dust depolarization ratio in Korea with the correction of the polarization-dependent transmission. Asia-Pacific Journal of Atmospheric Sciences, 49(1), 592 $19-25$.

593

Shin, S., Noh, Y. M., Lee, K., Lee, H., Müller, D., Kim, Y. J., Kim, K, and Shin, D., 2014:

Retrieval of the single scattering albedo of Asian dust mixed with pollutants using lidar observations. Advances in Atmospheric Sciences, 31(6), 1417-1426.

Shin, S. K., Müller, D., Lee, K. H., Shin, D., Kim, Y. J., and Noh, Y. M., 2015: Vertical 600 variation of optical properties of mixed Asian dust/pollution plumes according to pathway of airmass transport over East Asia. Atmospheric Chemistry and Physics, 15, 6707-6720.

601

Stocker, T.F., Qin, D., Plattner, G.-K., Tignor, M., Allen, S.K., Boschung, J., Nauels, A., Xia, 603 Y., Bex, V., Midgley, P.M., 2013: IPCC, 2013: Climate Change 2013: The Physical Science 604 Basis. Contribution of working group I to the fourth assessment report of the 605 intergovernmental panel on climate change. Cambridge University Press, Cambridge, United 606 Kingdom and New York, NY, USA.

607

Takemura, T., Nozawa, T., Emori, S., Nakajima, T. Y., \& Nakajima, T., 2005: Simulation of 609 climate response to aerosol direct and indirect effects with aerosol transport-radiation model. 610 J. Geophys. Res., 110, D02202, doi:10.1029/2004JD005029.

612 Tesche, M., Müller, D., Gross, S., Ansmann, A., Althausen, D., Freudenthaler, V., Weinzierl, 613 B., Veira, A., and Petzold, A., 2011: Optical and microphysical properties of smoke over Cape 
614 Verde inferred from multiwavelength lidar measurements. Tellus B, 63(4), 677-694.

615

616 Utry, N., Ajtai, T., Filep, Á., Pintér, M. D., Hoffer, A., Bozoki, Z., and Szabó, G., 2013: Mass

617 specific optical absorption coefficient of HULIS aerosol measured by a four-wavelength

618 photoacoustic spectrometer at NIR, VIS and UV wavelengths, Atmos. Environ., 69,321-324.

619 Volten, H., Munoz, O., Rol, E., Haan, J. D., Vassen, W., Hovenier, J. W., Muinonen, K., and

620 Nousiainen, T., 2001: Scattering matrices of mineral aerosol particles at $441.6 \mathrm{~nm}$ and 632.8

621 nm. J. Geophys. Res., 106, 17375-17401.

622

623 Yoon, S. C., Lee, Y. J., Kim, S. W., Kim, M. H., and Sugimoto, N., 2010: Measurements of 624 the Lidar ratio for asian dust and pollution aerosols with a combined raman and back-scatter 625 lidar. Journal of the Korean Meteorological Society, 20(4), 387-530. 

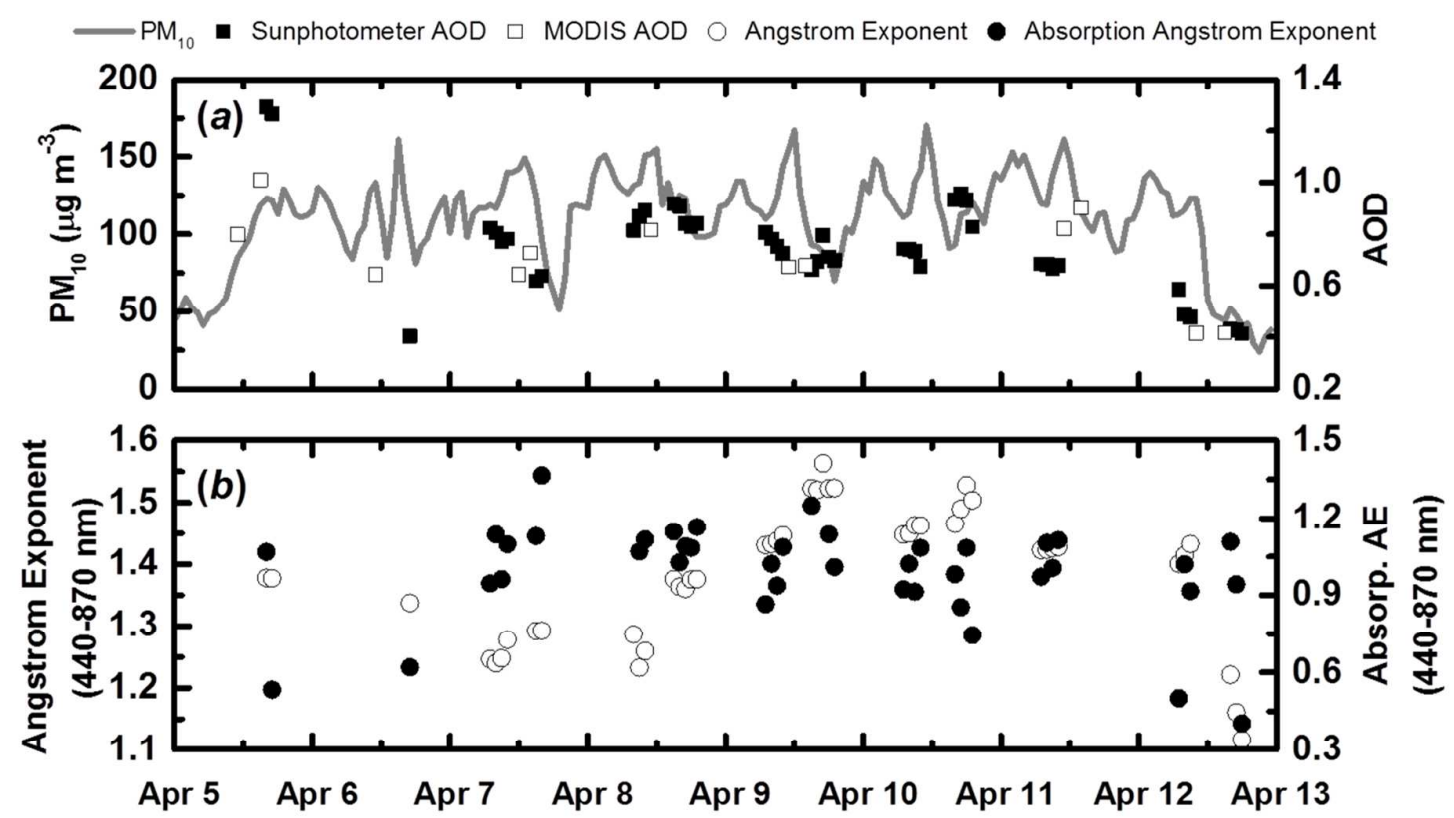

Fig. 1. (a) Time series of the $\mathrm{PM}_{10}$ concentration (gray line) measured with a beta gauge, the AERONET sun/sky radiometer AOD (black square) at $500 \mathrm{~nm}$, and MODIS AOD (open square) at $550 \mathrm{~nm}$ (b) Ångström exponent and absorption Ångström exponent (440-870 nm wavelength range) derived from the AERONET sun/sky radiometer data. 

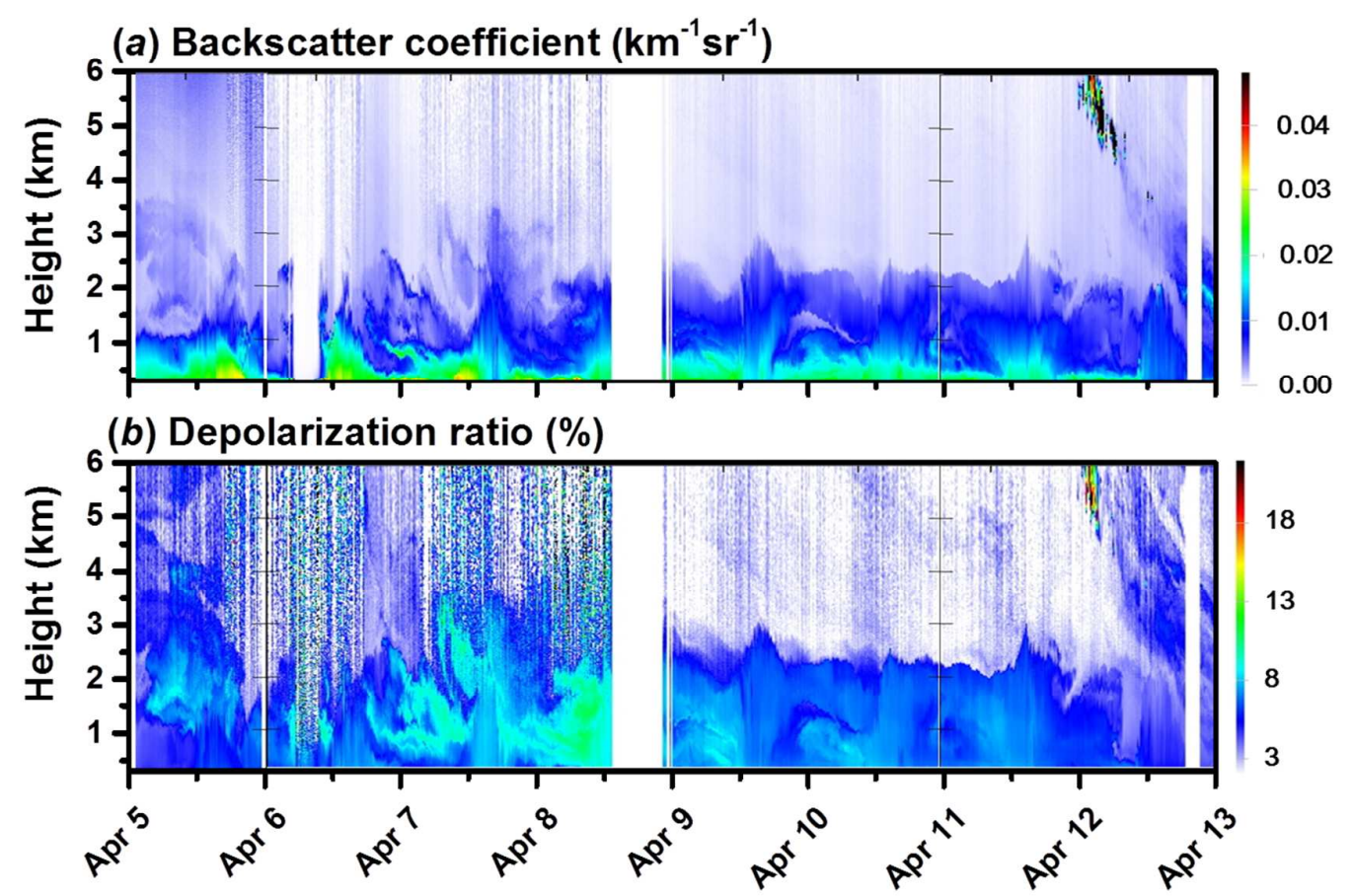

Fig. 2. Time-height cross-sections of (a) the $532 \mathrm{~nm}$ attenuated backscattered coefficient and (b) the linear volume depolarization ratios observed by the depolarization ratio lidar system between April 5 (00:00 LT) and 12 (24:00 LT) 2009. 


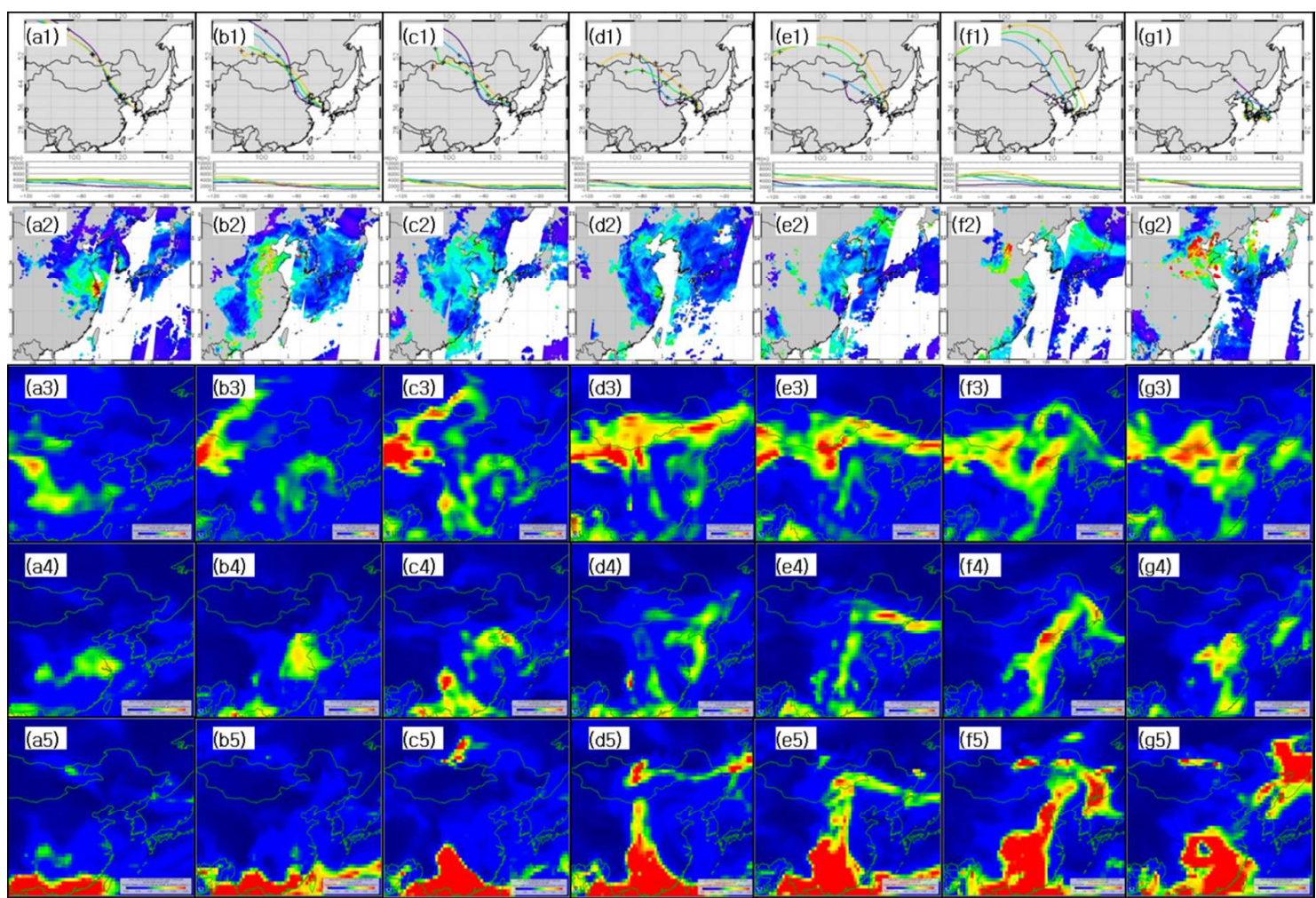

Fig. 3. Five-day HYSPLIT backward trajectory analysis (a1-g1), MODIS-derived aerosol optical depth at $550 \mathrm{~nm}(\mathrm{a} 2-\mathrm{g} 2)$, and the ECMWF-derived distributions of the aerosol optical depth for dust (a3-g3), black carbon (a4-g4), and organic matter (a5-g5) over East Asia for April 6 to 122009. 


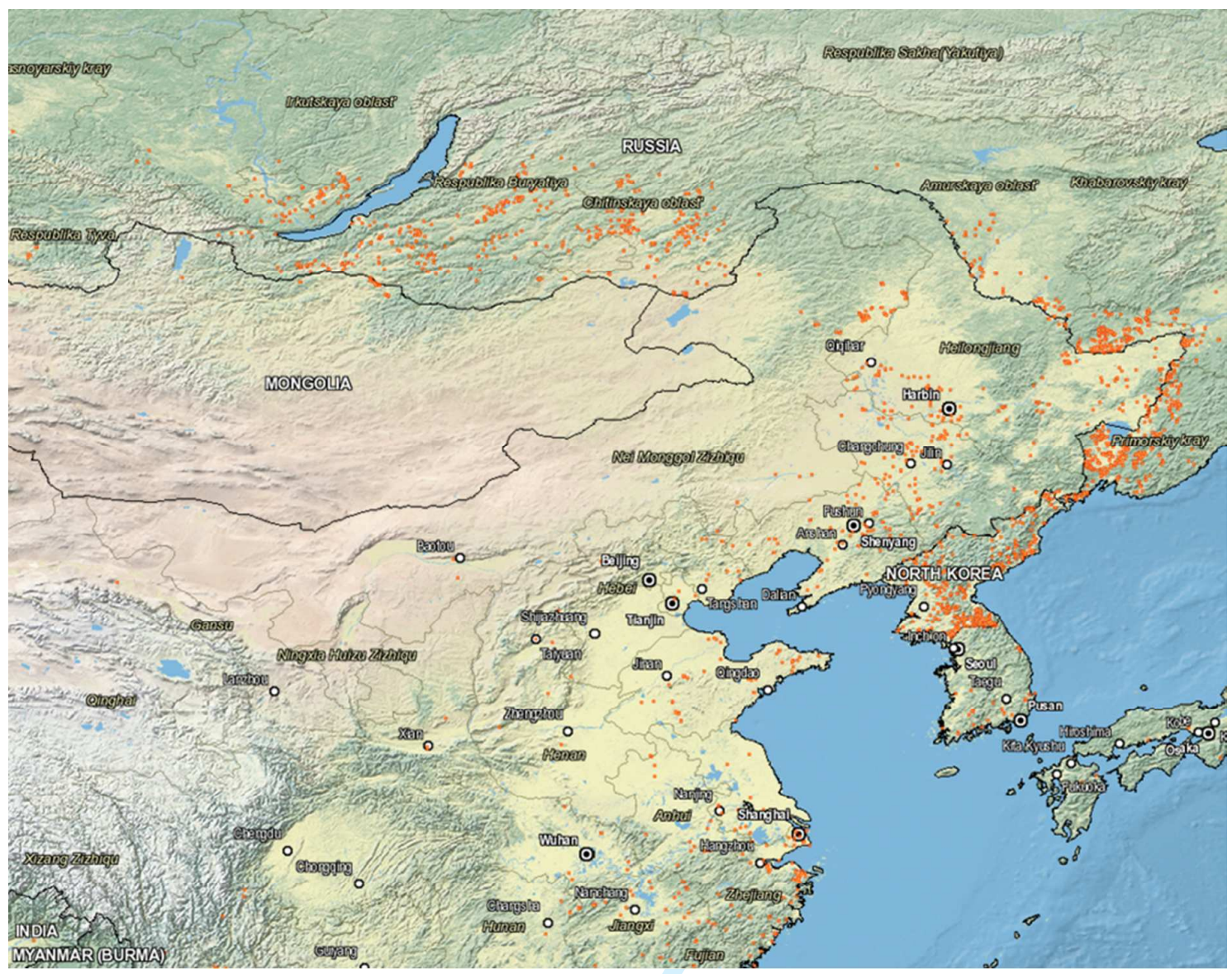

Fig. 4. MODIS active fire products for April 9-12 2009. 

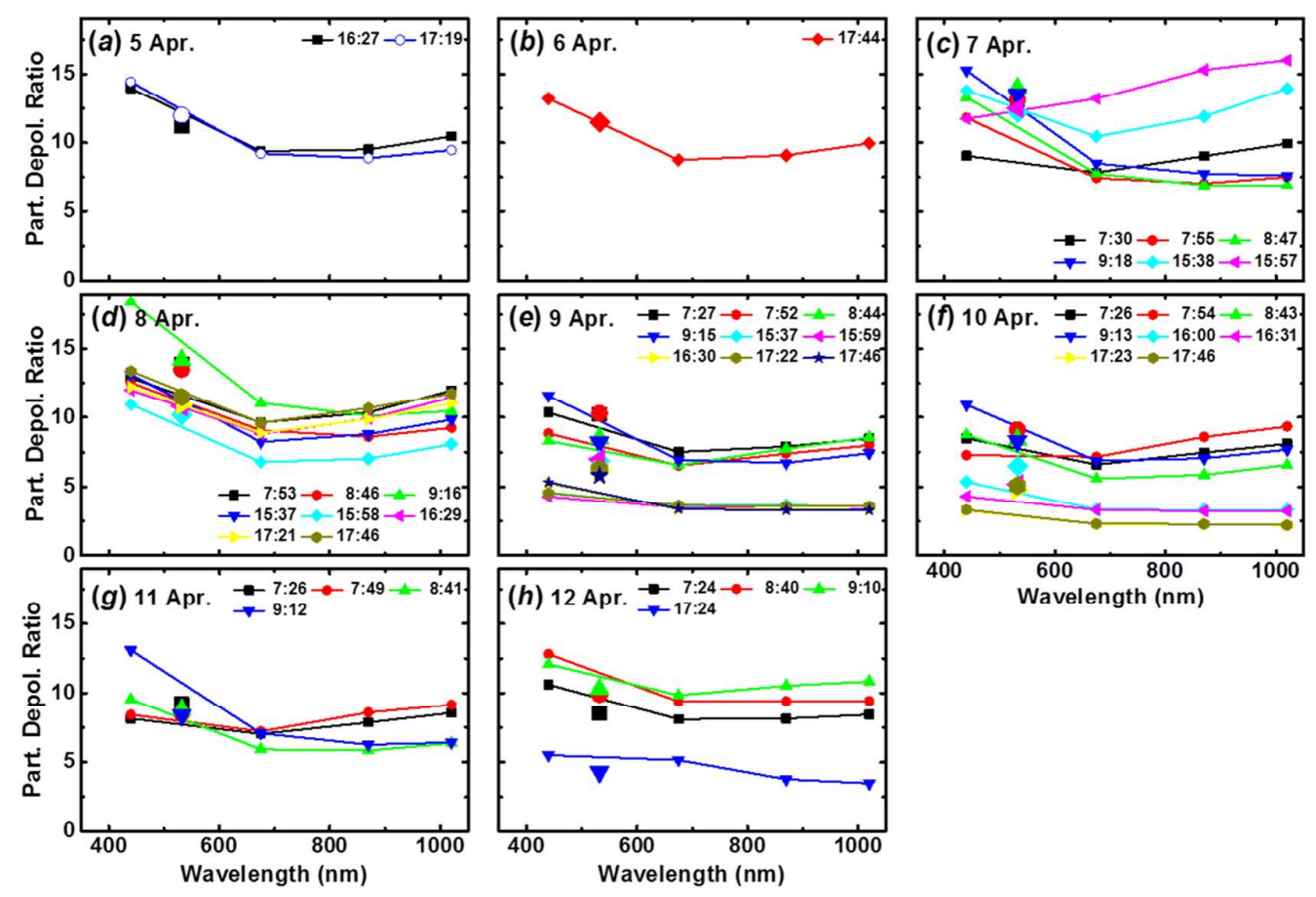

Fig. 5. Particle depolarization ratio at four wavelengths (440, 675, 870, and $1020 \mathrm{~nm})$ derived from the AERONET sun/sky radiometer data (dotted lines) and lidar-derived depolarization ratio (large dots) at $532 \mathrm{~nm}$. Lidar-derived DPRs are represented by dots, whereas the sun/sky radiometer-derived DPRs are represented by line with dot. Observation days and times are as in Fig. 2. 


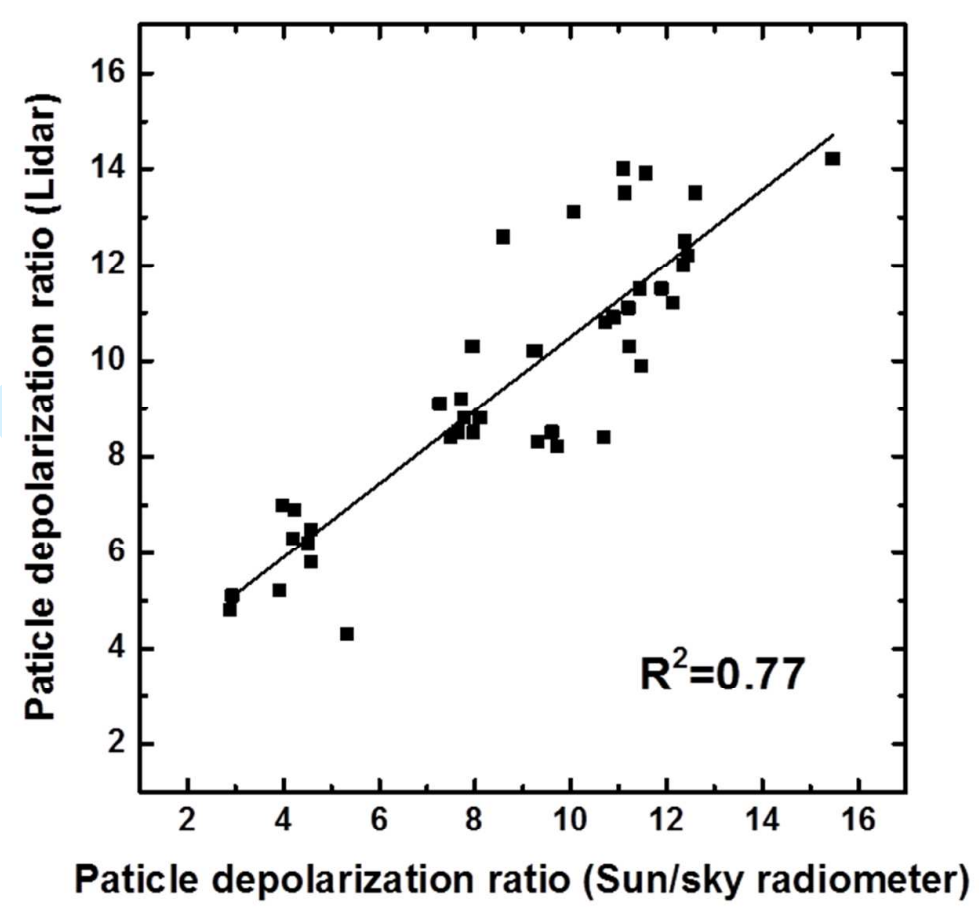

Fig. 6. Correlation plot of particle depolarization ratio at $532 \mathrm{~nm}$ derived by lidar and sun/sky radiometer data. The particle depolarization ratio of sun/sky radiometer at $532 \mathrm{~nm}$ was calculated by the linear regression method. 

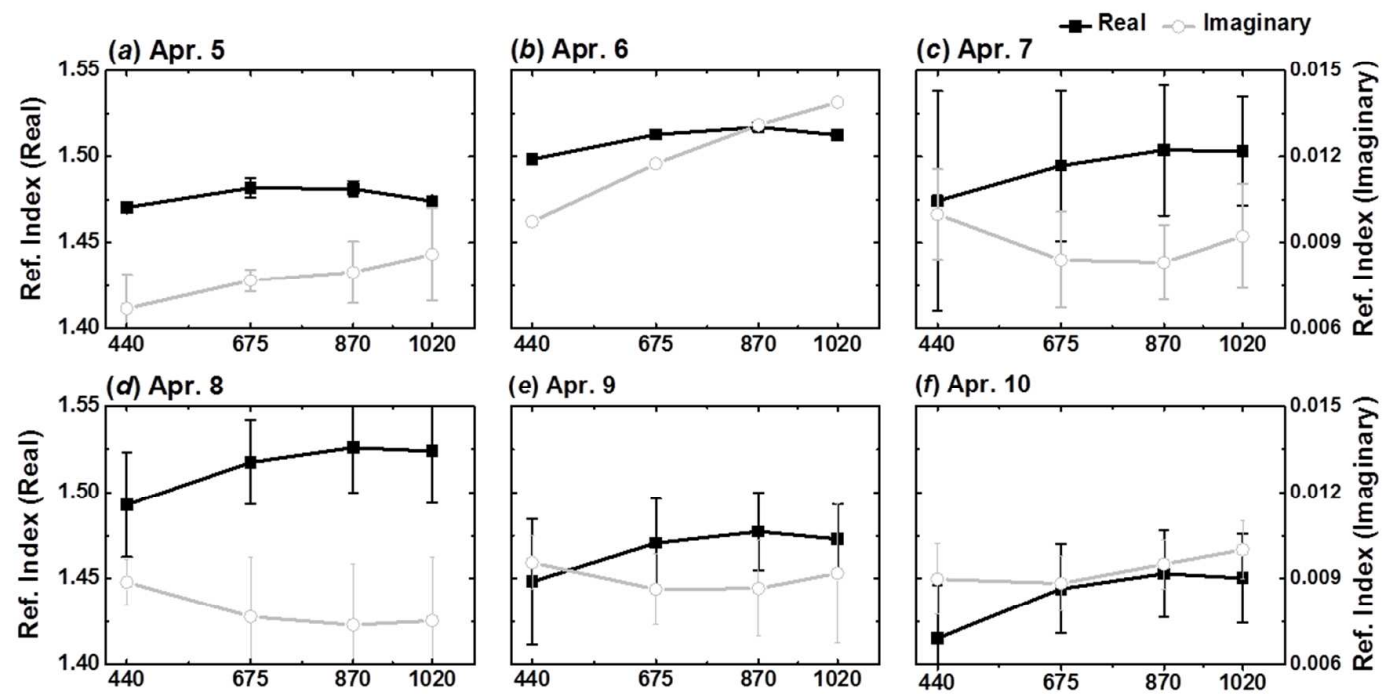

(e) Apr. 9
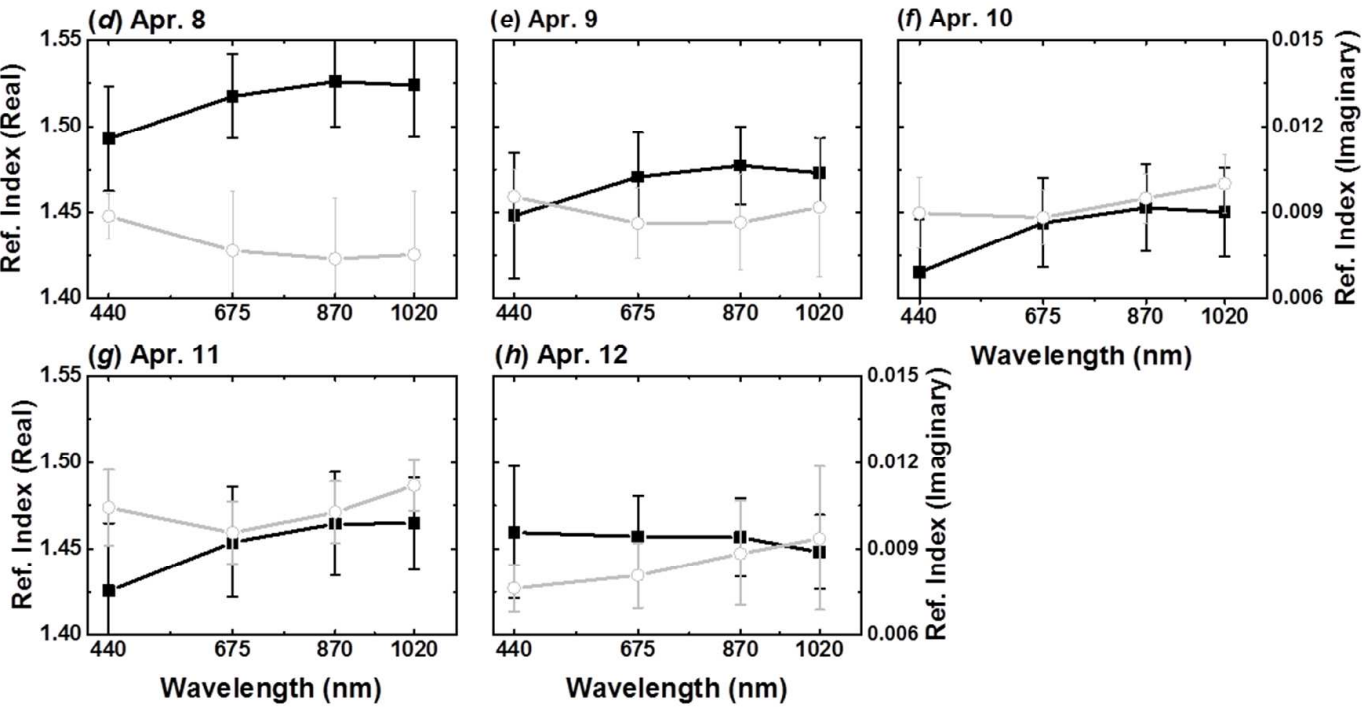

Fig. 7. Refractive index (real part (black squares) + imaginary part (open circles)) of particles with respect to the measured wavelengths $(440,675,870$, and $1020 \mathrm{~nm})$, as retrieved from the AERONET sun/sky radiometer measurements on April 5 to 12 2009. The number of measurement data for each day is the same in Figure 5. 

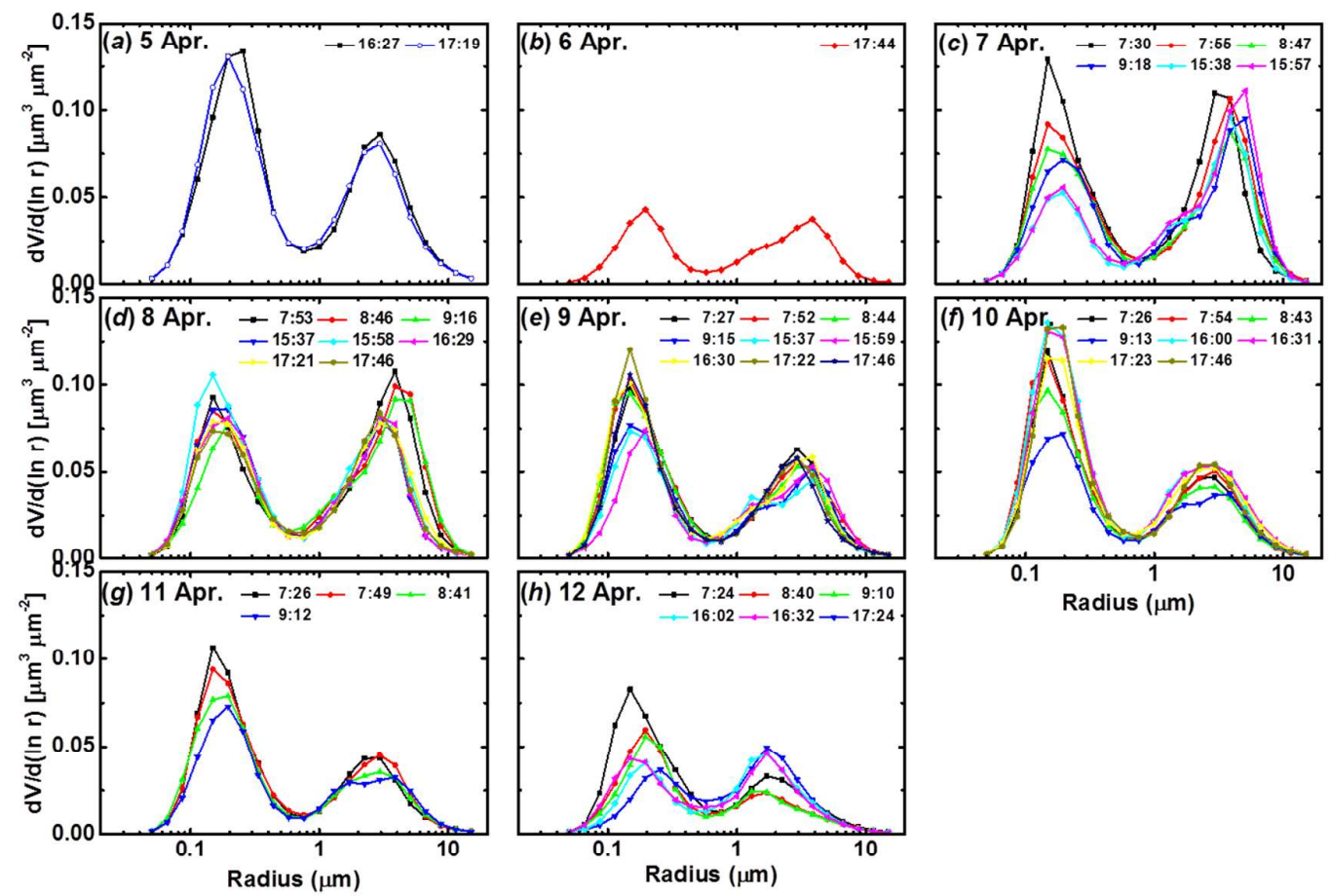

Fig. 8. Particle volume size distribution retrieved from the AERONET sun/sky radiometer on April 5 to 12 2009. Observation times are shown for each day. 

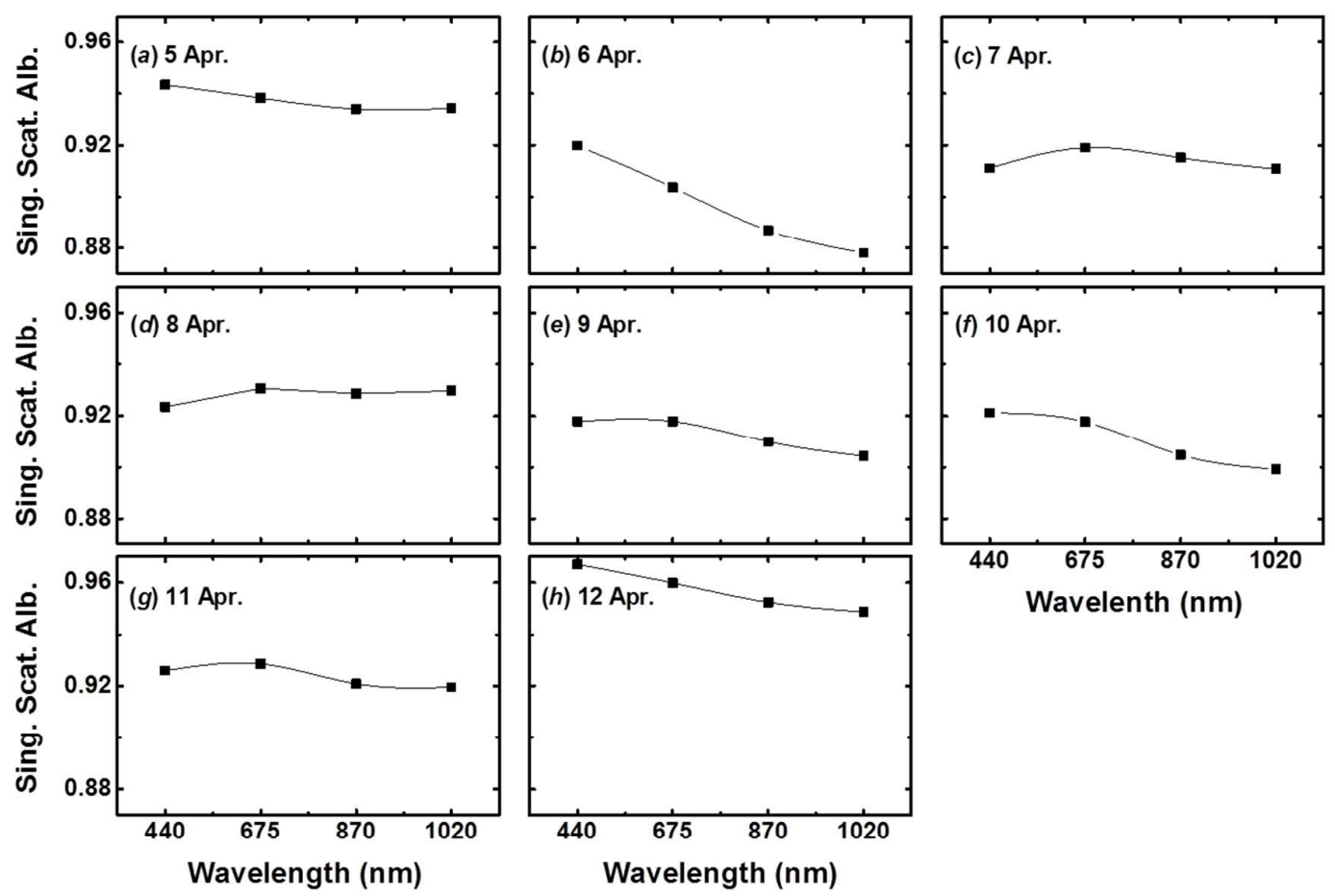

Fig. 9. Daily averaged spectral single scattering albedo at $440,675,870$, and $1020 \mathrm{~nm}$ by AERONET Version 2, Level 2.0 data from April 5 to 122009. 
Table 1. Daily average values of aerosol optical depth $(\tau)$ at $500 \mathrm{~nm}, \mathrm{AE}$, sun/sky radiometerderived particle depolarization ratios $\left(\boldsymbol{\delta}_{\mathrm{sp}}\right)$ at $440,675,870$, and $1020 \mathrm{~nm}$, and AAE.

\begin{tabular}{cccccccc}
\hline Date & \multirow{2}{\tau}{} & $\mathrm{AE}$ & \multicolumn{4}{c}{$\boldsymbol{\delta}_{\text {sp }}(\%)$} & AAE \\
& $(500 \mathrm{~nm})$ & $(440-870 \mathrm{~nm})$ & $440 \mathrm{~nm}$ & $675 \mathrm{~nm}$ & $870 \mathrm{~nm}$ & $1020 \mathrm{~nm}$ & $(440-870 \mathrm{~nm})$ \\
\hline 5 Apr. & $1.28 \pm 0.02$ & 1.38 & $14.2 \pm 0.3$ & $9.3 \pm 0.1$ & $9.2 \pm 0.4$ & $10.0 \pm 0.7$ & $0.80 \pm 0.38$ \\
6 Apr. & 0.40 & 1.34 & 13.2 & 8.8 & 9.1 & 10.0 & 0.62 \\
7 Apr. & $0.74 \pm 0.09$ & $1.27 \pm 0.02$ & $12.5 \pm 2.1$ & $9.2 \pm 2.2$ & $9.7 \pm 3.3$ & $10.3 \pm 3.8$ & $1.11 \pm 0.15$ \\
8 Apr. & $0.86 \pm 0.04$ & $1.33 \pm 0.06$ & $13.2 \pm 2.2$ & $9.0 \pm 1.2$ & $9.4 \pm 1.2$ & $10.5 \pm 1.4$ & $1.26 \pm 0.46$ \\
9 Apr. & $0.74 \pm 0.05$ & $1.49 \pm 0.05$ & $6.2 \pm 3.5$ & $5.0 \pm 1.8$ & $5.2 \pm 2.1$ & $5.5 \pm 2.5$ & $1.16 \pm 0.26$ \\
10 Apr. & $0.82 \pm 0.11$ & $1.48 \pm 1.43$ & $5.8 \pm 3.4$ & $4.7 \pm 2.1$ & $5.0 \pm 2.5$ & $5.3 \pm 2.9$ & $0.95 \pm 0.12$ \\
11 Apr. & $0.68 \pm 0.01$ & 1.43 & $9.8 \pm 2.3$ & $6.8 \pm 0.6$ & $7.1 \pm 1.3$ & $7.6 \pm 1.4$ & $1.05 \pm 0.07$ \\
12 Apr. & $0.47 \pm 0.06$ & $1.29 \pm 0.14$ & $12.0 \pm 3.8$ & $10.3 \pm 4.2$ & $10.3 \pm 4.8$ & $10.7 \pm 5.2$ & $0.81 \pm 0.29$ \\
\hline
\end{tabular}

